Original Paper http://ajol.info/index.php/ijbcs http://indexmedicus.afro.who.int

\title{
Agrarian systems dynamics of shea trees (Vitellaria paradoxa Gaertn) parklands in Northern Benin
}

\author{
Césaire Paul GNANGLE ${ }^{1}$, Sèwanou Hermann $\mathrm{HONFO}^{2 *}$ and Charlemagne GBEMAVO ${ }^{2}$ \\ ${ }^{1}$ Laboratory of Soil Sciences, Water and Environment, Agricultural Research centre at national vocation based \\ in Agonkanmey, National Institute of Agricultural Research of Benin, 01 BP 884 Principal Receipt Cotonou, \\ Republic of Benin. \\ ${ }^{2}$ Laboratory of Biomathematics and Forestry Estimations, Faculty of Agronomy Sciences, Department of \\ Management of Natural Resources, University of Abomey-Calavi, 04 BP 1525 Cotonou, Republic of Benin. \\ *Correspondent author; E-mail:honfosewanou@gmail.com; Tel: +229965 34705
}

\section{ACKNOWLEDGEMENTS}

The authors would like to acknowledge the Foreign Office of France through the Inter Institution Agency for the Research and Development (AIRD) which have granted this research by the Funds of Prior Solidarity (FSP) in the frame of the project of interdisciplinary and participative research on the interactions between ecosystems, climate and societies of West Africa (RIPIESCA).

\begin{abstract}
Vitellaria paradoxa represents an essential element of the agroforestry system for maintaining ecology durability in Sub-Saharan region Africa. The present study aimed at bringing out elements of changes and modification or mutation that have occurred in the management of shea parklands between 1960 and 2012 in northern Benin. The method of analysis-diagnosis of agrarian systems developed by the Unity of Formation and Research (UFR) of the Compared Agriculture and Agricultural Development was used. Based on a land diagnosis of two agricultural districts characterized by homogenous agro-ecologic and socioeconomic conditions, this method enabled to mark and to explain the diversity system of $V$. paradoxa, and to analyze the functioning and changes occurred between 1960 and 2012. The diagnosis revealed that the proliferation of mistletoe and trunk borers on shea trees, and the reduction of half of $V$. paradoxa stands and their density were the main changes observed in the villages. Furthermore, changes have occurred at the beginning and the end of farming activities, their period, the introduction of new crops and the recovered option of intensification. This study shows that there are changes in the management system of shea parklands in Benin.
\end{abstract}

(c) 2016 International Formulae Group. All rights reserved.

Keywords: Dynamics, agrarian systems, shea parklands, diagnostic analysis, Benin.

\section{INTRODUCTION}

The Neolithic time was the pioneer period of first farming and breeding systems (Mazoyer and Roudart, 1997). From that time to date, in most woody regions, the increasing of population led to deforestation and in certain cases to desertification. Then, fellingburning farming systems have given place to numerous successive post forester agrarian systems, quite differentiated according to the climate, and relatively independent from each other. In the same way, tool equipments have 
been improved and the frequency of feasible harvest has increased. According to Stigter (2010), arborous parklands can be assimilated to multiple farming. They can be planted in sequence the same year or simultaneously during the whole or a part of species vegetation cycle (or varieties cultivated) on the same land; each one could have similar or different farming cycle periods. The system of multiple farming of shea parklands, associates shea trees with crops especially cotton and food crops such as sorghum, maize, cowpea, yam, manioc, etc.

Shea tree is widely used in food manufacturing. In addition, it is known for its advantages as natural beauty products and for its advantages related to population health improvements by using its natural oils discovered at the time of recent researches (Gnanglè et al., 2012). As shea production industry wove links and built on these strengths, shea prices have increased (Stigter, 2010) at an amazing rate of 50\% since 2006. Shea tree plays an essential role in maintaining the ecological durability in Sahel and in Sub-Saharan Africa. In particular, it is harvested by about 4 million women in West Africa region and its fruits are an important and crescent source of income for local families and communities (Kpadonou et al., 2012; Gnanglè et al., 2012). Recent studies proved that 1,000 \& US invested in the beginning of the exploitation of shea, brought back 1,580 \$ to household incomes (Oluwasusi and Tijani, 2013). With a transformation capability of 12,000 tons to 35,000 tons of shea nuts harvested for exportation, Benin is an ideal place for sector intervenors to identify new investment opportunities which will profit both trade and local communities. This activity concerns almost the whole totality of women in northern of Benin (Akouehou et al., 2013).The analysis of the dynamics of agrarian systems at different spatio-temporal scales across the world, allowed to grasp the general movement of transformations in the time, and the differentiation in the farming area particularly the shea parklands. A theory of evolution stipulates that "an agrarian system cannot be analyzed outside the activities upstream that provide production means, the use of its products through activities downstream and consumers, or other agrarian systems that converge to the satisfaction of the society needs (Mazoyer and Roudart, 1997). Therefore, making use of this theory, a model of study of shea parklands can be proposed based on concepts and theories of the compared agriculture (Mazoyer and Roudart, 1997). This method analyzes the dynamics of production systems with the interface between the transformations of biophysical and socioeconomical environments. However, the present study aims at bringing out elements of change and modification or mutation occurred in the management of shea parklands between 1960 and 2012 in Northern Benin.

\section{MATERIALS AND METHODS Biological material}

The present study brings in interest $V$. paradoxa as it is socio-economically important for rural and urban populations. In west-northern Benin, $46 \%$ of household earnings come from shea trees (Akouehou et al., 2013). It is a real oleaginous source for populations from Northern Benin contrary to palm oil in Southern. It is also the third important product in terms of monetary income and exportation bulk in Benin. The species adapts to a rainfall varying between 600 to $1750 \mathrm{~mm} /$ year with one long dry season of 4 to 8 months (Akouehou et al., 2013). In Benin, its preferred region spread from Atcherigbe to over Kandi $\left(11^{\circ}\right.$ and $12^{\circ}$ $40^{\prime}-2^{\circ} 82^{\prime}$ ).

\section{Study area}

The present study was carried out in East-Northern Benin (Sudano-guinean transition zone and Sudanian zone) in two of the five parklands of Vitellaria paradoxa and Parkia biglobosa, identified by Gbédji (2003) and Gnanglè (2005) (Figure 1). These parklands were chosen according to their fruit production level and the perceptible effect of climatic variability on their agrarian systems. It concerns shea parklands of Parakou and Kandi. The parkland of $V$. paradoxa and $P$. biglobosa of Kandi is located between $11^{\circ}$ and $12^{\circ} 40^{\prime}-2^{\circ} 82^{\prime} \mathrm{N}$ and the one of Parakou 
ranges from $9^{\circ}$ to $10^{\circ} \mathrm{N}$. The investigations were conducted in two districts: Djougou (parkland of Parakou) and Malanville (parkland of Kandi).These districts were selected according to the proportion of people who use shea trees (50-80\%). The characteristics of the both sample villages are presented in the Table 1.

\section{Sampling method}

The statistic research unit was the owners of exploitation of over 45 years old. These types of interviewees may have sufficient and reliable information on climatic phenomenon (Gbetibouo, 2009). The sample size was determined per locality using the properties of binomial distribution (Dagnélie, 1998).

$N=\frac{4 p(1-p)}{d^{2}}(1)$

In this formula, $p$ represents the proportion of people who exploit shea trees in the locality; $d$ the chosen error deviation, here $10 \%$. The interviewees were randomly selected.

\section{Data collection and analysis}

The method used leans on the concepts and theories of compared agriculture (Mazoyer and Roudart, 1997). ). It takes a socioeconomic dimension including focus group, and a structured survey with key informers (Brottem, 2011). The survey was carried out through two steps. The first step aimed at defining the old dynamics and the new exploitation of the area. Data collected were related to the modifications that occurred in farming system, farming calendar, access mode to productive resources between 1960 and 2012.The second step consisted to a semistructured survey where qualitative data was collected on the history of stands, the indigenous knowledge on the management of rural landed systems, socio-economic and cultural shea value, and customs and farming techniques. For communication needs, old students who could speak both french and local languages were used as native guides. Before the real survey, translators were taught about the survey's method and the list of questions. However, 8 women $(10 \%$ of sample size) were randomly chosen in order to get the local technology of shea butter life story.

The rate of answer per standard question was shown by the formula 2 :

$$
f=100 \frac{s}{N}
$$

$\mathrm{f}$ : the answer rate; $\mathrm{S}$ : number of interviewers providing a positive answer in relation to a question; $\mathrm{N}$ : total number of interviewees. Data provided from focus group were discussed.

\section{RESULTS}

\section{Local knowledge on shea trees and history of stands}

The results show there are some mutations in the shea tree agro-forestry agrarian systems. The fruition of the species is unknown by $98.78 \%$ of interviewees. The majority of farmers underlined the drastic decline of $V$. paradoxa density between 1960 and 2012. The estimated mean density of shea trees was 23 trees / ha in 1960 and 10 trees / ha 2012. In the village Kpali, farmers distinguished 3 varieties of $V$. paradoxa: $V$. paradoxa with big fruit, $V$. paradoxa with extend and smooth leaves; V. paradoxa with middle fruit and hairy leaves, and V. paradoxa with little folded fruit and hairy leaves. Whereas, in the village of Tomboutou, farmers distinguished 2 varieties: $V$. paradoxa with early growth and $V$. paradoxa with late growth. Generally, all interviewees assert not to have observed any change about characteristics of different varieties from 1960 to 2012. Local populations of both villages consume $V$. paradoxa and use its different organs and products: leaves, branches, bark, root, flower, fruit, knob, pulp, epicarp, crab, latex, etc.

\section{Agrarian systems dynamics of $\boldsymbol{V}$. paradoxa parklands}

The dynamics of agrarian systems is essentially related to the variation of factors such as: the rights of farming land access for foreigners and natives, the charges concerning land access, farming systems and agriculturebreeding relations, the schedule of farm activities and the work distribution between men, women and children, the rights of 
picking access of $V$. paradoxa fruits and rituals related to $V$. paradoxa nuts collecting.

Tables 2 and 3 show a comparison of the schedules of both villages in the two periods (1960 and 2012), that led to the understanding of the mutations occurred in the agrarian system especially farming activities. Therefore, the change at the beginning and the end of farming operations, their period, introduction of new crops and a new option of intensification, are the main modifications. In addition, women can have access to land in Tomboutou. However, they cannot transfer it to a foreigner, on contrary to Kpali village. We notice intensification orientated to market gardening in Tomboutou village.

\section{Main factors of changes}

Changes that occurred in agrarian system are mostly due to demographic growth, the introduction of new technologies, the soil fertility and the landed pressure. Its manifestations are more perceptible in Tomboutou, characterized by the reduction of the fallow period, the high pressure on land and the frequent conflicts between farmers and cattle-breeders. The introduction of animal traction, the low period of fallow, the systematic fruits collection and the land pressure, have many negative impacts on the regeneration of $V$. paradoxa. Generally, the variation observed on crops choice is related to adaptations to climatic variability especially to water stress and to the decrease in soil fertility. In order to guarantee expected yields from crops, farmers used to foresee climatic risks. Indeed, farmers depend on that activity for vital needs. In Tomboutou, farmers insisted particularly on the dryness occurred in 1970 and the reduction in rainfall amount noticed for 80 years, the proliferation of mistletoe and borers of $V$. paradoxa trunk. By seeking fodder for cattle, Peulh breeders mutilate trees in particular V. paradoxa, and as a result, destroy the biodiversity of the species in Tomboutou village. Nowadays, very little women are interested to the manufacturing of shea butter because of the small available quantity of knob: climatic and human factors contribute manifestly to the low productivity of $V$. paradoxa in the region.

Table 1: Agronomic and socio-economic characteristics of study villages.

\begin{tabular}{|c|c|c|}
\hline Characteristics & Tomboutou village & Kpali village \\
\hline Shea parkland of membership & Kandi & Parakou \\
\hline Agro-ecological zone & Extreme Northern Benin & Western Atacora \\
\hline Township & Malanville & Djougou \\
\hline Localisation & $\begin{array}{c}11^{\circ} 84^{\prime} 30.6^{\prime \prime} \mathrm{N} \\
\text { and } 3^{\circ} 24^{\prime} 96.6^{\prime \prime} \mathrm{E}\end{array}$ & $\begin{array}{c}09^{\circ} 38^{\prime} 30.47^{\prime \prime} \mathrm{N} \\
\text { and } 1^{\circ} 48^{\prime} 24.27^{\prime \prime} \mathrm{E}\end{array}$ \\
\hline Climate & Sudano-shelian & Sudanian \\
\hline Rainfall mean (mm) & 900 & 1000 to 2000 \\
\hline Mean temperature $\left({ }^{\circ} \mathrm{C}\right)$ & 29 & 26.60 \\
\hline Cultural cycle period & 120 & 140 \\
\hline Main ethnic groups & Dendi & Yom \\
\hline Main activities & $\begin{array}{c}\text { Breeding, fishing, } \\
\text { agriculture }\end{array}$ & Breeding, fishing, agriculture \\
\hline Main crops & $\begin{array}{c}\text { Peanut, tomato, pepper, } \\
\text { okra, potato, onion, } \\
\text { cotton and manioc }\end{array}$ & $\begin{array}{c}\text { Cashew tree, cotton, } \\
\text { maize, sorghum and } \\
\text { manioc. }\end{array}$ \\
\hline Fallow period (year) & 1 to 2 & 5 to 10 \\
\hline
\end{tabular}


Table 2: Kpali cultural schedule of 1960 and 2012.

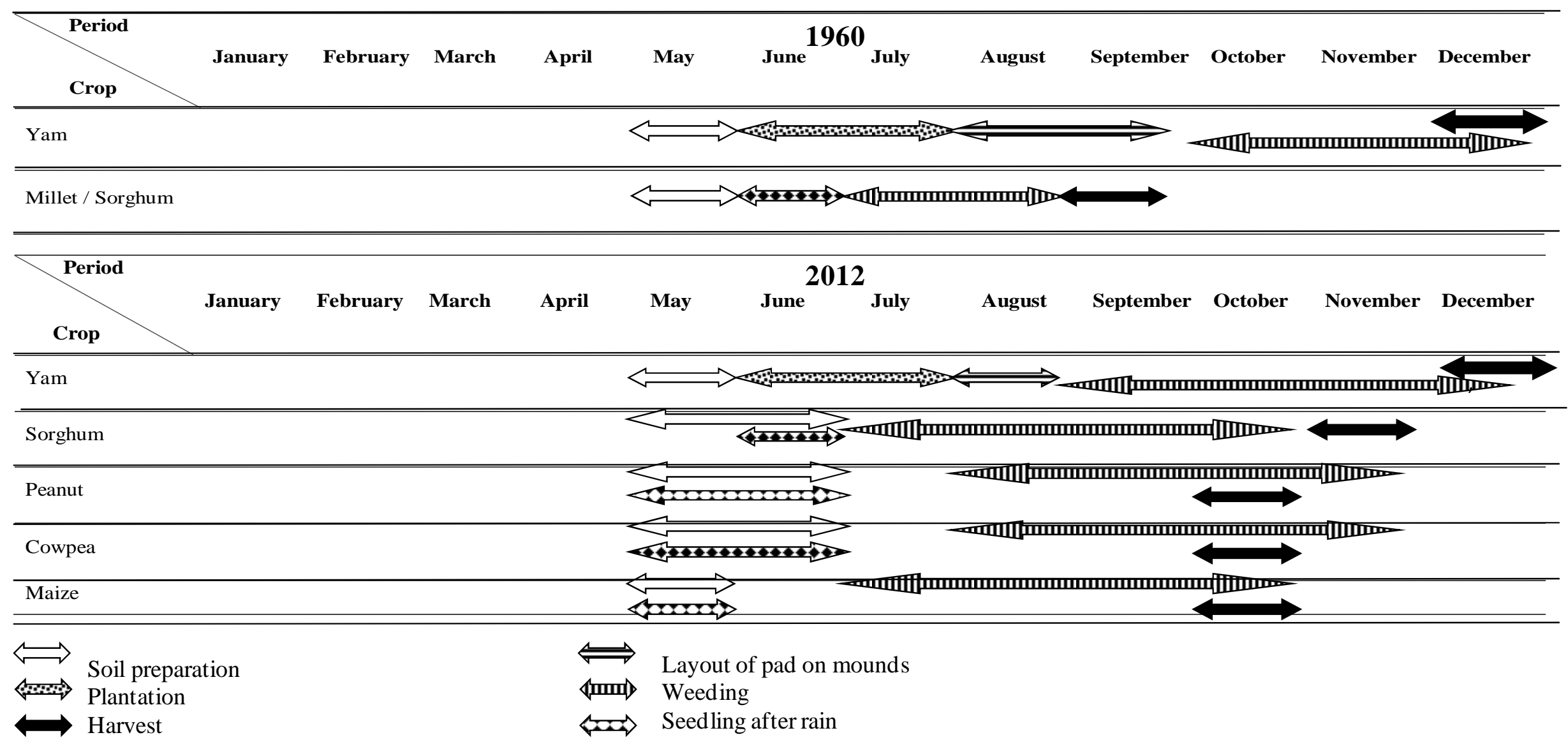


Table 3: Tomboutou cultural schedule of 1960 and 2012.

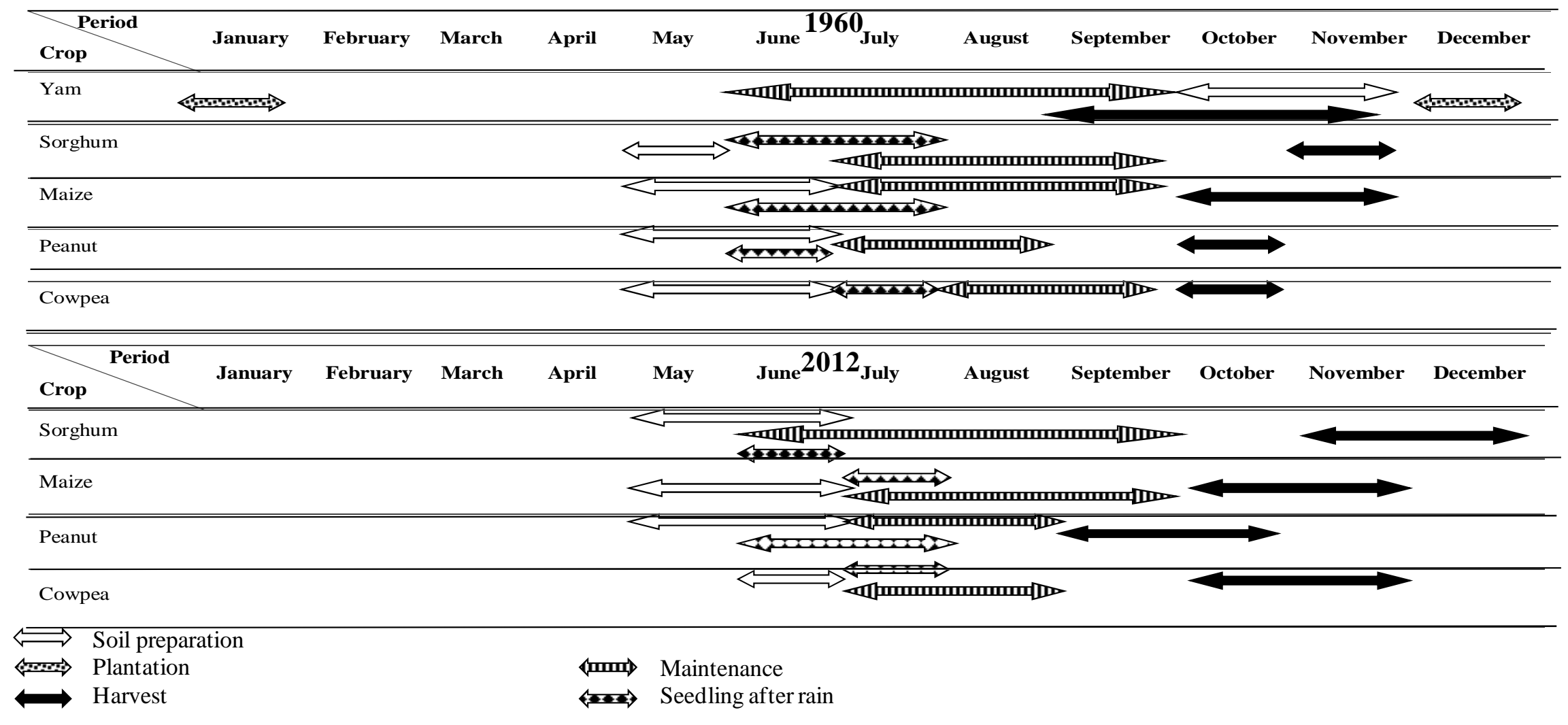




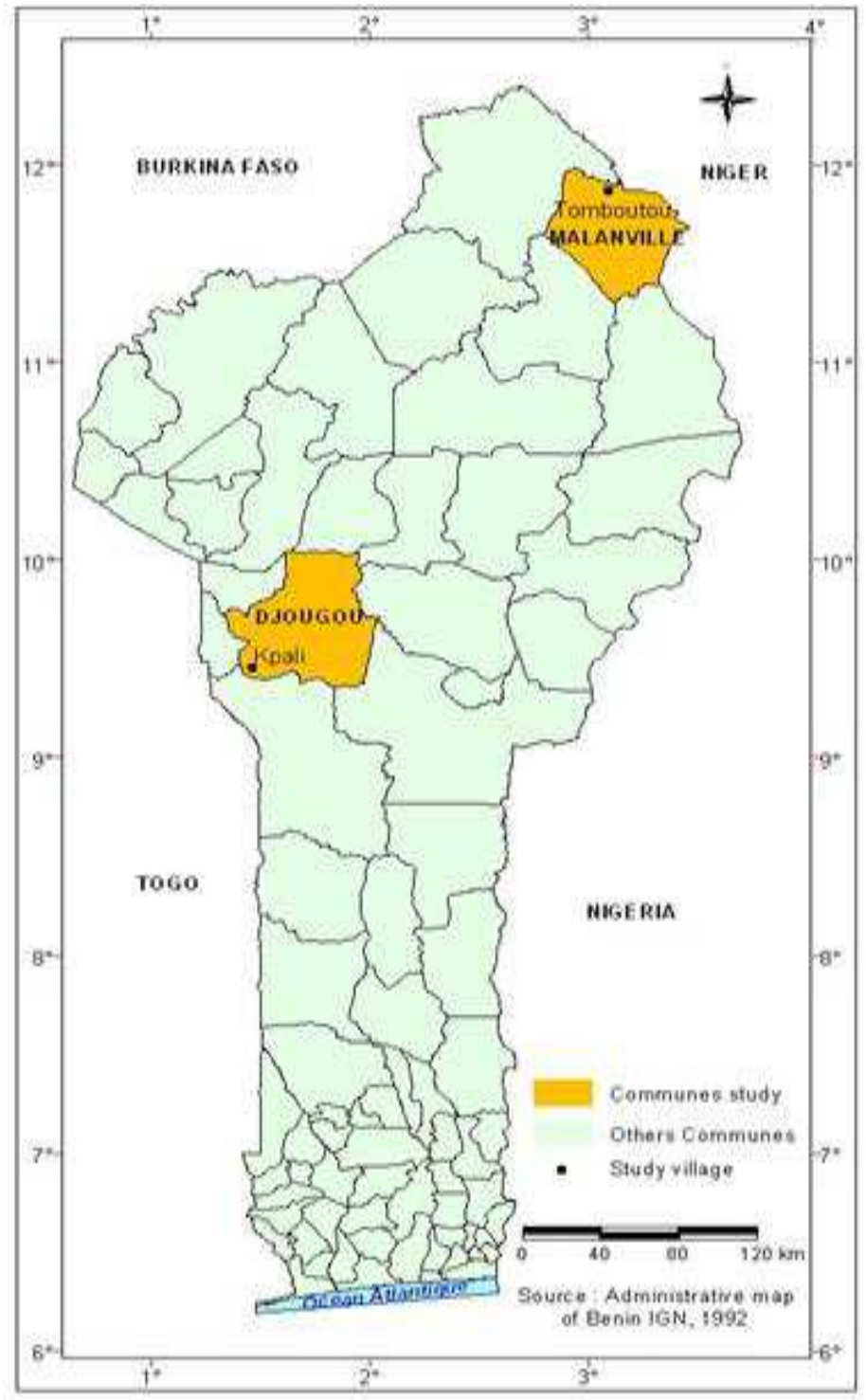

Figure 1: Study area.

\section{DISCUSSION}

Local knowledge in shea parklands management

Most of farmers recognized the existence of $V$. paradoxa morphotypes that show phenotypic variability observed in rural region. This diversity, maintained by farmers, could be the result of an active selection process exerted on natural stands in order to conserve genetic characters which present a particular interest to them. That is a good result for $V$. paradoxa and $P$. biglobosa grafting. This result confirms the one of (Diarassouba et al., 2008), when they study local knowledge in shea parklands management in Ivory Coast. A minority of farmers can specify the age of $V$. paradoxa when it fructifies for the first time. Diarassouba et al. (2008) also found out that less than half of the farmers interviewed know 
the first time of shea fruiting. The difference between that result and the one presented by this study could be attributed to the difference in knowledge by the informants on the species. A kind of report seems to be in contradiction with numerous uses that the populations make of this resource. According to some socio-cultural groups (Bariba, Dendi in Benin and Senoufo, Lobi, Tagbanan in Ivory Coast), V. paradoxa is a grant from God (Sanou et al., 2004) as the seed grows without any treatments. The legend of certain ethnic groups said that anyone who plants a $V$. paradoxa die as soon as it produces or he won't have enough time to benefit of $V$. paradoxa production usufruct (Gnanglè, 2005; Diarassouba et al., 2008). This kind of believes disheartens shea orchard establishment and could be an obstacle to the species domestication. That situation is predominant in Tomboutou village. Indeed, the species is cut down and the collection of its fruits is done early (the fruit are collected while they are green) because of the land pressure, the unavailability of feeding during difficult periods, and the weakness of earnings. These fruits are either eaten directly by populations or sold at Malanville border market. It is worth noticing that shea trunk borers (Neoplocaedaerus sp., Coleoptera: Cerambycidae) enough fearsome, slay 5 to 10 trees per ha and per year in infested zones (Gnanglè et al., 2012).

Surveys achieved with farmers show the main function of shea association with other crops, system done by every farmer interviewed. Shea resources are exploited under many forms by local populations. They were named mostly in traditional medicine. More, the multitude of sickness treatments and the similarity of recipes used by various interviewees show that $V$. paradoxa has great medicinal and pharmacological potentialities. However, many natural stands were destroyed by colonists, who had authority to favor cotton culture and other cash crops. Natural stands domestication and conservation in situ efforts are considered. Shea parklands exploitation in most regions is submitted to lands access mode. These results of research are also verified in Ivory Coast by Diarassouba et al. (2008). According to this author, any offense to this rule is punished according to tradition and custom of the community to which belongs the offender, but not always. Indeed, the present study shows that the agrarian system varies according to the cultural norms of each village. The changes in agrarian system are also related to the demographic pressure, the introduction of animal traction, new techniques, decreasing of the fallow period. The access to land refers to specific rights «rights of land access», to other resources (tree for example), to benefits and to the responsibilities bound to these rights (Evers, 2005).

\section{Changes in management of shea parklands and land tenure}

Data analysis shows that populations of both villages respond dynamically to agricultural intensification process (Lund, 2007; Brottem, 2011). In both villages, the intensification impacted agrarian system of shea parklands as farmers have reduced the fallow periods; and have developed practices of land tenure, and adapted their household economies to the crescent penury of $V$. paradoxa products. As farmers have reduced the fallow periods, that became less important to provide visual evidence to land tenure since fields are cultivated without break and cannot be learned so easily as asked by other. These results confirm the one found by previous studies on non timber forest products conservation (Teklehaimanot, 2004; Gnanglè, 2005; Brottem, 2011).

\section{Changes in the life mode of populations and shea tree regeneration}

Household life conditions are remarkably changed as shea butter is nowadays weakly used by agricultural households. Light oils are presently used because of their easy access (DahDovononetal., 2006) and the local cooking 
that used shea butter has been regressing. These results are in accordance with the ones of Brottem (2011) who noticed that $P$. biglobosa households' consumption is decreasing, especially soumbala consumption in Mali and Burkina-Faso or affitin in the plateau of Abomey in Benin (Gutierrez et al., 2002). The study also pointed out the obsolete state of the shea transformation industry. Indeed, shea churning was made in calabashes, the cooking in big jars. The knob grinding was made onto a stone transported by at least two men, who carry it to the village. Transformers used raffia wood to stir the butter. In conditions of the observed intensive farming in agrarian systems of shea parklands, it is urgent to establish tree nursery and to realize vegetative multiplication of $V$. paradoxa. Otherwise, this species could progressively disappear.

The establishment of a dialogue framework to manage conflicts between farmers and cattle-breeders in Tomboutou village which forbid vegetation fire is a projection in protection of $V$. paradoxa wild stocks. If this framework does not exist in Kpali village, the animal's stampings and the low period of fallow could be real constraints for $V$. paradoxa regeneration.

\section{COMPETING INTERESTS}

The authors declare that they have no competing interests.

\section{AUTHORS' CONTRIBUTIONS}

CPG worked in each step of the elaboration of this paper. SHH worked on the writing and the correction of the paper, as well as the translation of the paper from French to English. CG worked on the data collection and analysis steps.

\section{REFERENCES}

Akouehou GS, Assogba DO, Houndonougbo A, Sinsin AB. 2013. Diversité floristique, sécurisation foncière et gestion des systèmes agroforestiers à palmier à huile (Elaeis guineensis) en zones périurbaines et rurales du Département de l'Atlantique au Sud du Bénin. Int. J. Biol. Chem. Sci., 7(3): 1180-1189, DOI : http:// ajol.info/index.php/ijbcs

Brottem L. 2011. Rediscovering "Terroir" in West African Agroforestry Parklands. Society and Natural Resources. Taylor \& Francis Group, LLC. DOI: 10.1080/08941920903377012. 24:553568.

Dagnelie P.1998. Statistiques Théoriques et Appliquées. De Boeck et Larcier: Brussels, Belgium.

Diarassouba N, Kouablan EK, N'Guessan KA, Van Damme P, Sangaré A. 2008. Local knowledge and its use in the management of shea parklands in Ivory Coast. Afrika Focus, 21:77-96.

Evers S, Spierenburg M, Wels H. 2005. Competing jurisdictions: Settling Land Claims in Africa. Leiden, the Netherlands: Brill.

Gbédji EKY. 2003. Morphological and structural characterization of mimosa parklands (Parkia biglobosa (Jack;) R. Br. Ex. G. Dom.) in Benin. Agricultural Engineer Thesis, University of AbomeyCalavi, Benin, p. 124.

Gbetibouo GA. 2009. Understanding Farmers' Perceptions and Adaptations to Climate Change and Variability: The Case of the Limpopo Basin, South Africa. IFPRI Discussion Paper 00849. 41p.

Gnanglè CP. 2005. Shea parklands (Vitellaria paradoxa) (Gaertn. C. F.) (Sapotaceae) in Benin: Importance of socio-cultural, morphological, structural and natural regeneration characterizations. DEA Thesis. University of Abomey-Calavi, Benin, p. 113.

Gnangle PC, Egah J, Baco MN, Gbemavo CDSJ, Kakai R, Sokpon N. 2012. Perceptions locales du changement climatique et mesures d'adaptation dans la gestion des parcs à karité au NordBénin. Int. J. Biol. Chem. Sci., 6(1): 136- 
149. DOI: http://ajol.info/ index.php/ijbcs

Gutierrez ML, Juhe-Beaulaton D. 2002. Story of mimosa (Parkia biglobosa Jacqu. Benth.) parkland in table land of Abomey (Benin) : of its conservation for the production and the marketing of a condiment, afitin. Overseas books, Bordeaux, 220: 453-474.

Kpadonou RAB, Adégbola PY, Tovignan SD. 2012. Local knowledge and adaptation to climate change in Ouémé valley, benin. African Crop Science Journal, 20(2): 181 - 192.

Lund C. 2007. Local politics and the dynamics of property in Africa. Cambridge University Press: Cambridge, UK.

Oluwasusi JO, Tidjani SA. 2013. Farmers adaptation strategies to the effect of climate variation on yam production: a case study in ekiti state, nigeria. Agrosearch, 13(2): 20-31. DOI: http://dx.doi.org/10.4314/agrosh.v13i2.3

Sanou H, Sie K, Teklehaimanot Z, Dembele M, Yossi H, Sina S, Djingdia L, Bouvet JM. 2004. Vegetative propagation of Vitellaria paradoxa by grafting. Agroforestry Systems, 60: 93-99.

Stigter K. 2010. Applied Agrometeorology. Springer; Heidelberg Dordrecht London; New York.

Teklehaimanot Z. 2004. Exploiting the potential of indigenous agroforestry trees: Parkia biglobosa and Vitellaria paradoxa in sub-Saharan Africa. Agrofor. Systems, 61-62(1-3): 207-220. 